\title{
PROSEDUR PENCATATAN PENERIMAAN DAN PENGELUARAN KAS PADA LEMBAGA PERKREDITAN DESA (LPD) DESA ADAT SULAYAH KECAMATAN SERIRIT
}

\author{
Ketut Catur Eka Sari Dewi \\ Jurusan Akuntansi Program Diploma III, \\ Universitas Pendidikan Ganesha, Singaraja \\ catureka48@yahoo.com
}

\begin{abstract}
Abstrak
Penelitian ini bertujuan untuk mengetahui, Prosedur Pencatatan Penerimaan dan Pengeluran Kas Pada Lembaga Perkreditan Desa (LPD) Desa Adat Sulanyah Kecamatan Seririt.Teknik pengumpulan data yang digunakan yakni, metode wawancara dan dokumentasi. Objek penelitian adalah prosedur pencatatan penerimaan dan pengeluaran kas, dan subjek penelitian adalah Lembaga Perkreditan Desa (LPD) Desa Adat Sulanyah Kecamatan Seririt. Data yang digunakan adalah data kualitatif.

Hasil penelitian menunjukan bahwa Prosedur Pencatatan Penerimaan dan Pengeluaran Kas Pada Lembaga Perkreditan Desa (LPD) Desa Adat Sulanyah Kecamatan Seririt ada 6 prosedur diantaranya : (1) Pencatatan Penerimaan Kas Pada Tabungan, (2) Pencatatan Penerimaan Kas Pada Deposito, (3) Pencatatan Pengeluaran Kas Pada Tabungan, (4) Pencatatan Pengeluaran Kas Pada Pencairan Deposito, (5) Pencatatan Pengeluaran Kas Pada Pencairan Kredit, dan (6) Pencatatan Penerimaan dan Pengeluaran Kas Akhir. Prosedur Pencatatan Penerimaan dan Pengeluaran Kas Pada Lembaga Perkreditan Desa (LPD) Desa Adat Sulanyah Kecamatan Seririt sudah sesuai dan memadai, ini dapat dilihat dari proses pencatatan penerimaan dan pengeluaran kas yang ada pada Lembaga Perkreditan Desa (LPD) tersebut.
\end{abstract}

Kata Kunci : Prosedur, Penerimaan Kas, Pengeluaran Kas, Lembaga Perkreditan Desa (LPD).

\begin{abstract}
This study aims to determine the Recording Procedures of Cash Receipts and Expenditures in Lembaga Perkreditan Desa (LPD) Desa Adat Sulanyah, the district of Seririt. The techniques used for data collection are namely, interview and documentation. The object of the study is the recording procedures of cash receipts and expenditures, and the subject of the study is Lembaga Perkreditan Desa (LPD) Desa Adat Sulanyah, the district of Seririt. The data used are qualitative data. Furthermore, the data will be analyzed by using qualitative descriptive analysis.

The result shows that the recording procedures of cash receipts and expenditures in lembaga perkreditan desa (Ipd) desa adat sulanyah, the district of seririt contains 6 procedures that include: (1) the recording of cash receipts on savings, (2) the recording of cash receipts on deposits, (3) the recording of cash disbursement on savings, (4) the recording of cash disbursement on deposit liquidation, (5) the recording of cash disbursement on loan disbursement, and (6) the recording of final cash receipts and expenditures. The Registration procedures of Cash Receipts and Expenditures in Lembaga Perkreditan Desa (LPD) Desa Adat Sulanyah, the district of Seririt iss appropriate and adequate, it can be seen from the process of recording of cash receipts and payments that exists in Lembaga Perkreditan Desa (LPD). The accounting note used in the process of the recording of cash receipts and payments can be described with a flow chart, procedures for the recording of cash receipts and disbursements.
\end{abstract}

Keywords: Procedures, Cash Receipts, Cash Disbursement, Lembaga Perkreditan Desa (LPD).

\section{Pendahuluan}

Kemajuan suatu Negara dapat diukur dengan tingkat pertumbuhan ekonominya. Negara yang memiliki tingkat pertumbuhan ekonomi yang baik, tidak terlepas dari peran Lembaga Keuangan. Di Indonesia, Lembaga Keuangan dibagi menjadi dua yaitu lembaga 
keuangan bank dan lembaga keuangan non-bank. Salah satu lembaga keuangan non-bank yang diterapkan di Indonesia, khususnya di Bali adalah Lembaga Perkreditan Desa (LPD). Meskipun dengan manajemen yang sederhana, Lembaga Perkreditan Desa (LPD) mampu memberikan manfaat-manfaat bagi masyarakat desa sebagai berikut: (1) memberikan pelayanan yang lebih mudah untuk menyesuaikan dengan situasi dan kondisi masyarakat, (2) memberikan pelayanan yang tersebar dan menjangkau berbagai sektor usaha masyarakat, (3) sebagian dari laba Lembaga Perkreditan Desa (LPD) langsung dapat dimanfaatkan untuk mendanai kegiatan adat, sehingga merupakan salah satu unit usaha Desa Adat, (4) mendukung pengembangan ekonomi dalam berbagai sektor di masyarakat Desa (Partamawati, 2009).

Lembaga Perkreditan Desa (LPD) Desa Adat Sulanyah merupakan salah satu Lembaga Perkreditan Desa (LPD) di Kecamatan Seririt. Lembaga Perkreditan Desa (LPD) ini didirikan sejak hari Kamis, tanggal 25 April 2001, berdasarkan Ketentuan/keputusan Lembaga Perkreditan Desa (LPD) Desa Adat Sulanyah. Dimana menyatakan bahwa Lembaga Perkreditan Desa (LPD) milik Desa Adat/Krama Desa merupakan wadah/kekayaan desa yang bertujuan untuk, menunjang dan meningkatkan taraf hidup masyarakat serta memberikan modal kepada masyarakat/karma Desa Adat Sulanyah untuk membuat usaha.

Lembaga Perkreditan Desa (LPD) Desa Adat Sulanyah merupakan lembaga keuangan yang menghimpun dan menyalurkan dana masyarakat yang beroperasi pada suatu wilayah administrasi desa adat dengan berdasarkan atas kekeluargaan. Lembaga Perkreditan Desa (LPD) Desa Adat Sulanyah sebagai lembaga yang bergerak di bidang keuangan, tentu saja dalam kegiatannya sehari-hari tidak terlepas dari transaksi penerimaan dan pengeluaran kas. Seiring dengan perkembangan Lembaga Perkreditan Desa (LPD), sejumlah transaksi yang terlibat semakin kompleks.

Kas merupakan aktiva yang paling aktif dan sangat penting bagi perusahaan, dibandingkan aktiva-aktiva lain yang dimiliki perusahaan. Dalam hal ini hampir semua transaksi perusahaan akhirnya akan mempengaruhi kas, baik itu menyangkut penerimaan kas maupun pengeluaran kas. Biasanya kas dengan mudah diselewengkan pada saat siklus transaksi kas. Kas merupakan aktiva yang paling likuid, oleh karena itu kas harus dikelola dengan baik untuk menghindari penyelewengan-penyelewangan atas kas tersebut.

Untuk itu Lembaga Perkreditan Desa (LPD) harus membuat suatu prosedur pencatatan penerimaan dan pengeluaran kas yang dirancang sedemikian rupa sehingga kas yang masuk atau keluar dalam perusahaan dapat diproses melalui tahap-tahap dari prosedur tersebut. Karena pencatatan penerimaan dan pengeluaran kas yang baik dapat mendorong dipatuhinya kebijaksanaan-kebijaksanaan yang diterapkan oleh Lembaga Perkreditan Desa (LPD) Desa Adat Sulanyah. Mengingat kas merupakan obyek yang sering diselewengkan, karena kas merupakan aktiva yang paling likuid dari aktiva lainnya dan juga karena bentuknya yang kecil, tidak diketahui pemiliknya, dapat dipindahtangankan dengan cepat serta diperlukan setiap orang. Hampir semua jenis perusahaan memusatkan perhatian pada pengendalian yang efektif dan efisien, yang tujuannya untuk menghindari kemungkinan penyelewengan dan kecurangan terhadap penggunaan kas

\section{Metode Penelitian}

Tujuan yang ingin dicapai dari penelitian ini adalah untuk mengetahui Prosedur Pencatatan Penerimaan dan Pengeluaran Kas Pada Lembaga Perkreditan Desa (LPD) Desa Adat Sulanyah Kecamatan Seririt. Pada penelitian ini, data yang dipergunakan adalah data kualitatif yang merupakan focus utama dari tujuan penelitian. Agar tujuan penelitian dapat tercapai, maka peneliti melakukan pengumpulan data dengan (1) Penelitian Kepustakaan (Library Research) yaitu dengan cara membaca, mengumpulkan, mempelajari dan mencatat bahan-bahan yang berhubungan dengan penelitian ini yang didapat dari buku-buku, artikel, jurnal maupun dari internet yang berkaitan dengan Lembaga Perkreditan Desa (LPD), prosedur pencatatan penerimaan dan 
pengeluaran kas. (2) Studi Lapangan (Field Research) yaitu dengan 2 metode: metode interview atau wawancara yaitu dengan mengajukan pertanyaan dalam wawancara langsung, dengan cara mewawancarai pegawai LPD (kasir) untuk mendapatkan informasi atau data-data untuk menambah perolehan data sehingga mempermudah dalam penyelesaian tugas akhir dari penelitian ini. Seperti mengajukan pertanyaan penerapan Prosedur Pencatatan Penerimaan dan Pengeluaran Kas di Lembaga Perkreditan Desa (LPD). Dan metode dokumentasi yaitu mencari dan mengumpulkan data mengenai hal-hal yang terkait dengan penelitian, berupa data-data atau catatan-catatan yang berkaitan dengan Prosedur Pencatatan Penerimaan dan Pengeluaran Kas, jumlah anggota, struktur organisasi beserta tugas dan wewenang, dan sejarah perusahaan. Data yang telah terkumpul akan dianalisis dengan analisis deskriptif kualitatif. Teknik analisis deskriptif kualitatif merupakan cara menganalisis dengan menguraikan, menyusun, mengklasifikasikan, dan mengdeskriptifkan tentang prosedur pencatatan penerimaan dan pengeluaran kas. Langkah dalam pengujian penelitian ini adalah membuat bagan alir (flowchat) untuk prosedur pencatatan penerimaan dan pengeluaran kas, dan mendeskripsikan bagan alir (flowchat) tersebut.

\section{Hasil dan Pembahasan}

\section{Prosedur Pencatatan Penerimaan dan Pengeluaran Kas Pada Lembaga Perkreditan Desa (LPD) Desa Adat Sulanyah Kecamatan Seririt}

Berikut ini adalah prosedur-prosedur pencatatan penerimaan dan pengeluaran kas secara garis besar antara lain :

\section{a. Prosedur Pencatatan Penerimaan Kas Pada Tabungan}

Prosedur pencatatan penerimaan kas pada tabungan yaitu diawali dari nasabah langsung datang ke Lembaga Perkreditan Desa (LPD) dengan membawa uang yang akan ditabung dan membawa Buku Tabungan. Nasabah membawa uang dan Buku Tabungan diserahkan ke Bagian Umum, Bagian Umum menerima uang dan Buku Tabungan Nasabah. Selanjutnya Bagian Umum menghitung uang nasabah dan memeriksa keaslian uang. Setelah itu Bagian Umum mengisi Bukti Kas Masuk (BKM) rangkap 2 dengan lengkap disertai tanda tangan, selanjutnya mengisi jumlah setoran pada Buku Tabungan dan mengisi jumlah setoran pada form Prima Nota/ Tabungan dengan mengisi jumlah mutasi kredit dan debet beserta saldo akhir tabungan nasabah. Kemudian uang, Bukti Kas Masuk (BKM) rangkap 2, Buku Tabungan dan form Prima Nota/Tabungan diserahkan ke Bagian Kasir. Selanjutnya Bagian Kasir menyimpan uang di dalam brangkas. Bukti Kas Masuk (BKM) lembar ke 2 dan buku tabungan diserahkan kepada Nasabah, sedangkan Bukti Kas Masuk (BKM) lembar ke 1 dan form Prima Nota/Tabungan dicatat ke Daftar Penerimaan Kas dan di arsip sesuai dengan tanggal sebagai bukti penyetoran.

\section{b. Prosedur Pencatatan Penerimaan Kas Pada Deposito}

Prosedur pencatatan penerimaan kas pada deposito yaitu diawali dari kedatang Nasabah ke Lembaga Perkreditan Desa (LPD) dengan membawa uang yang akan didepositokan, Buku Tabungan dan fotocopy KTP. Nasabah membawa uang dan Buku Tabungan diserahkan ke Bagian Umum, Bagian Umum menerima uang, Buku Tabungan Nasabah dan fotocopy KTP. Selanjutnya Bagian Umum menghitung uang nasabah dan memeriksa keaslian uang. Setelah itu Bagian Umum mengisi Bukti Kas Masuk (BKM) dan form Surat Simpanan Berjangka (SSB) masing-masing rangkap 2 dengan lengkap disertai tanda tangan. Kemudian uang, Bukti Kas Masuk (BKM) rangkap 2, Buku Tabungan dan form Surat Simpanan Berjangka (SSB) rangkap 2 diserahkan ke Bagian Kasir. Selanjutnya Bagian Kasir menyimpan uang di dalam brangkas. Bukti kas masuk (BKM) lembar ke 2, Buku Tabungan dan Surat Simpanan Berjangka (SSB) lembar ke 1 diserahkan kepada Nasabah, sedangkan Bukti Kas Masuk (BKM) lembar ke 1 dan Surat Simpanan Berjangka (SSB) lembar ke 2 dicatat ke Daftar Penerimaan Kas dan di arsip sesuai dengan tanggal sebagai bukti penyetoran. 
VOL.9 NO. 1 JULI 2018

p-ISSN : 2338-6177

\section{c. Prosedur Pencatatan Pengeluaran Kas Pada Tabungan}

Prosedur pencatatan pengeluaran kas pada tabungan yaitu diawali dari nasabah langsung datang ke Lembaga Perkreditan Desa (LPD) dengan membawa Buku Tabungan. Nasabah membawa Buku Tabungan diserahkan ke Bagian Kasir, Bagian Kasir menerima Buku Tabungan nasabah dan selanjutnya Bagian Kasir mengisi Bukti Kas Keluar (BKK) rangkap 2 dengan lengkap disertai tanda tangan. Kemudian Bagian Kasir mengisi jumlah penarikan pada Buku Tabungan dengan mengisi jumlah mutasi kredit dan debet beserta saldo akhir tabungan nasabah, dan juga mengisi jumlah penarikan pada form Prima Nota/ Tabungan. Selanjutnya Bagian Kasir menghitung uang yang telah dicairkan. Uang, Buku Tabungan dan Bukti Kas Keluar (BKK) lembar ke 2 diserahkan kepada Nasabah, sedangkan Bukti Kas Keluar (BKK) lembar ke 1 dan form Prima Nota/Tabungan dicatat ke Daftar Pengeluaran Kas dan di arsip sesuai dengan tanggal sebagai bukti penyetoran.

\section{d. Prosedur Pencatatan Pengeluaran Kas Pada Pencairan Deposito}

Prosedur pencatatan pengeluaran kas pada pencairan deposito yaitu diawali dari Nasabah langsung datang ke Lembaga Perkreditan Desa (LPD) membawa Surat Simpanan Berjangka (SSB) lembar ke 1 (SSB yang dibawa merupakan arsipan nasabah pada saat pendepositoan), Buku Tabungan dan fotocopy KTP. Nasabah membawa Surat Simpanan Berjangka (SSB) lembar ke 1, Buku Tabungan dan fotocopy KTP diserahkan ke Bagian Kasir, Bagian Kasir menerima Surat Simpanan Berjangka (SSB) lembar ke 1, Buku Tabungan dan foto copy KTP. Selanjutnya bagian kasir mengisi bukti kas keluar (BKK) rangkap 2 dengan lengkap disertai tanda tangan, dan mengisi form Surat Simpanan Berjangka (SSB) rangkap 2 (dimana SSB lembar ke 1 yang dibawa oleh Nasabah dan SSB lembar ke 2 merupakan dokumen arsipan kasir) dengan lengkap disertai tanda tangan. Kemudian Bagian Kasir menghituang uang yang telah dicairkan. Selanjutnya uang, Bukti Kas Keluar (BKK) lembar ke 2, Buku Tabungan dan Surat Simpanan Berjangka (SSB) lembar ke 2 diserahkan kepada Nasabah, sedangkan Bukti Kas Keluar (BKK) lembar ke 1 dan Surat Simpanan Berjangka (SSB) lembar ke 1 dicatat ke Daftar Pengeluaran Kas dan di arsip sesuai dengan tanggal sebagai bukti penyetoran.

\section{e. Prosedur Pencatatan Pengeluaran Kas Pada Pencairan Kredit}

Prosedur pencatatan pengeluaran kas pada pencairan kredit yaitu diawali dari kedatangan Nasabah ke Lembaga Perkreditan Desa (LPD) untuk meminta formulir permohonan kredit yaitu Surat Permohonan Kredit (SPK), kemudian mengisi Surat Permohonan Kredit (SPK) tersebut sesuai dengan syarat-syarat yang telah ditentukan. Dan juga Nasabah membawa fotocopy KTP suami istri, fotocopy Kartu Keluarga (KK) dan Jaminan. Selanjutnya Surat Permohonan Kredit (SPK), fotocopy KTP suami istri, fotocopy Kartu Keluarga (KK) dan Jaminan diserahkan kepada Kepala LPD. Kemudian Kepala LPD menilai kelayakan usaha debitur serta menilai barang yang dijaminkan. Selanjutnya dilakukan perhitungan dan pengumpulan informasi di atas kertas apakah calon debitur layak atau tidak untuk diberikan kredit. Kepala LPD juga melaksanakan investigasi berkas permohonan atau permintaan kredit, survey kelapangan dan membuat surat keputusan. Selain tugas itu, Kepala LPD juga mempunyai kewenangan menolak kredit dan menerima kredit yang telah diajukan oleh nasabah (calon debitur). Selanjutnya, apabila permohonan kredit sudah disetujui dan telah diotorisasi, kemudian berkas permohonan kredit seperti Surat Permohonan Kredit (SPK), fotocopy KTP suami istri, fotocopy Kartu Keluarga (KK) dan Jaminan diserahkan ke bagian umum. Lalu bagian umum membuat dokumen berupa Surat Perjanjian Pinjaman (SPP), Bukti Pengeluaran Kredit (BPK) rangkap 2, Bukti Kas Keluar (BKK) rangkap 2, Kitir Kredit dan Prima Nota Kredit. Untuk jaminannya dibuatkan Surat Penerimaan Jaminan (SPJ), Surat Kuasa Menjual Jaminan (SKMJ), pengikat jaminan disahkan oleh notaris (bila diperlukan) sehingga mempunyai kekuatan hukum bagi LPD. Kemudian Surat Permohonan Kredit (SPK), fotocopy KTP suami istri, fotocopy Kartu Keluarga (KK) dan 
Jaminan akan diarsip oleh bagian umum sebagai arsip bukti LPD. Setelah itu, dokumen seperti Surat Perjanjian Pinjaman (SPP), Surat Penerimaan Jaminan (SPJ), dan Surat Kuasa Menjual Jaminan (SKMJ) akan diarsip oleh bagian umum sebagai arsip bukti LPD. Sedangkan Bukti Pengeluaran Kredit (BPK) rangkap 2, Bukti Kas Keluar (BKK) rangkap 2, Kitir Kredit dan Prima Nota Kredit diserahkan ke bagian kasir. Setelah menerima berkas dari bagian umum, bagian kasir menghitung uang yang telah dicairkan. Uang, Kitir Kredit, Bukti Kas Keluar (BKK) dan Bukti Pengeluaran Kredit (BPK) lembar ke 2 diserahkan kepada nasabah, sedangkan Prima Nota Kredit, Bukti Kas Keluar (BKK) dan Bukti Pengeluaran Kredit (BPK) lembar ke 1 dicatat ke Daftar Pengeluaran Kas dan di arsip sesuai dengan tanggal sebagai bukti penyetoran.

\section{f. Prosedur Pencatatan Penerimaan dan Pengeluaran Kas Akhir}

Prosedur Pencatatan Penerimaan dan Pengeluaran Kas Akhir yaitu Bagia Kasir mengumpulkan daftar penerimaan dan pengeluaran kas dan dijumlahkan atau ditotalkan, dengan rumus jumlah penerimaan kas dikurangi pengeluaran kas maka didapatkan jumlah uang yang ada di brangkas. Setelah itu uang dihitung, apakah sudah cocok atau balance antara uang yang di brangkas dengan catatan yang dilakukan Bagian Kasir. Apabila sudah balance maka Bagian Kasir melakukan pencatatan selanjutnya yaitu: membuat laporan mutasi kas dan membuat berita acara kas untuk mempermudahkan pihak-pihak yang berkepentingan mengetahui banyaknya uang yang keluar-masuk ke brangkas.

\section{Simpulan dan Saran}

Berdasarkan hasil penelitian dan pembahasan maka dapat disimpulkan bahwa dalam prosedur pencatatan penerimaan dan pengeluaran kas pada Lembaga Perkreditan Desa (LPD) Desa Adat Sulanyah Kecamatan Seririt ada 6 prosedur diantaranya : (1) Pencatatan Penerimaan Kas Pada Tabungan, (2) Pencatatan Penerimaan Kas Pada Deposito, (3) Pencatatan Pengeluaran Kas Pada Tabungan, (4) Pencatatan Pengeluaran Kas Pada Pencairan Deposito, (5) Pencatatan Pengeluaran Kas Pada Pencairan Kredit, dan (6) Pencatatan Penerimaan dan Pengeluaran Kas Akhir. Dengan adanya prosedur pencatatan penerimaan dan pengeluaran kas pada Lembaga Perkreditan Desa (LPD) Desa Adat Sulanyah Kecamatan Seririt dapat diminimalisir kesalahan pencatatan, sehingga proses pencatatan penerimaan dan pengeluaran kas dapat dilakukan dengan tepat dan sesuai dengan aturan atau prosedur yang berlaku. Prosedur pencatatan penerimaan dan pengeluaran kas pada Lembaga Perkreditan Desa (LPD) Desa Adat Sulanyah Kecamatan Seririt juga sudah sesuai dengan tugas dan tanggungjawab dari masing-masing bagian yang ada di Lembaga Perkreditan Desa (LPD) tersebut.Namun dalam pelaksanaannya tidak menutup kemungkinan terjadi kesalahan yang dilakukan oleh kasir yaitu kekeliruan dalam pencatatan ataupun penghitungan uang, untuk mengatasi hal tersebut kasir harus mengkorenksi atau memeriksa dari awal pencatatan dan menghitung kembali uang yang diperoleh agar seimbang antara catatan dengan uang yang ada di brangkas.

Jadi dengan adanya prosedur pencatatan yang dilakukan oleh kasir dalam hal penerimaan dan pengeluaran kas diharapkan dapat mengurangi terjadinya penyelewengan kas, penyalahgunaan kas dan membantu proses pembuatan laporan keuangan yang tepat dan akurat.

Berdasarkan kesimpulan diatas, penulis dapat mengajukan saran kepada Lembaga Perkreditan Desa (LPD) Desa Adat Sulanyah Kecamatan Seririt bahwa dalam pencatatan penerimaan dan pengeluaran kas harus sesuai dengan aturan atau prosedur yang berlaku terutama yang dilakukan oleh Bagian Kasir. Dan Bagian Kasir dalam melakukan pencatatan dan perhitungan uang juga harus lebih teliti dan berhati-hati agar tidak terjadi kesalahan dalam pencatatan dan perhitungan uang, sehingga tidak akan terjadi penyelewengan atau penyalahgunaan terhadap kas. 


\section{Daftar Pustaka}

Achun.2007.Akuntansi Penerimaan dan Pengeluaran Kas. (Online) (http://zulidamel. wordpress.com, diakses pada tanggal 8 Februari 2015).

Anak Agung Wisnu Wasista.2015.Efektivitas Penyaluran Kredit Pada Lembaga Perkreditan Desa (LPD) Desa Tukatmungga Singaraja Tahun 2009-2013.

Baridwan,Zaki.1998.Sistem Akntansi Penyusunan Prosedur dan Metode Yogyakarta: BPEE.

Bertanlanffy,LudwigVon.1996. Pengertian Sistem (Online) (http://ilmucomputer2.blogsport. com, diakses pada tangggal 8 februari 2015).

Frida Septina.2012.Prosedur Pencatatan Penerimaan Dan Pengeluaran Kas Pada PT.Bank BTPN Tbk Kecamatan Singaraja.

I Gusti Ngurah Agung Yudiawan.2011.Analisis Sumber Dan Penggunaan Modal Kerja Pada LPD Desa Sibetan Kabupaten Karangasem Periode 2008-2010.

Kadek Krismaya Dewi dan IGA M Asri Dwijaputri.2014.Pengaruh Penerapan Prinsip-Prinsip GCG Pada Kinerja Keuangan Lembaga Perkreditan Desa Kabupaten Gianyar Provinsi Bali.

Kasmir.2001.Bank dan Lembaga Keuangan Lainnya.Edisi Revisi.Jakarta:PT.Raja Grafindo Persada.

Mulyadi. 2012.Sistem Akuntansi.Penerbitan Salem Empat.

Prof. Dr. Ali Afifuddin, SE. Pengertian Bank (Online) (http://id.wikipedia.org/wiki/Bank, diakses pada tanggal 6 Februari 2015).

Pakpahan,Hombar.2009.Pengertian Kas (Online). (http://ilmucomputer2.blogsport.com, diakses pada tanggal 6 Februari 2015).

Taswan.1997.Akuntansi Perbankan.Yogyakarta:Akademik Manajemen Perusahaan YKPN. 